\title{
Social Emotional Climate and Social Well-being in a Sample of Public Transport Users of the Southern Zone of Greater Buenos Aires
}

\author{
Della Pittima María Luciana ${ }^{1, ~ *, ~ D e p a u l a ~ P a b l o ~ D o m i n g o ~}{ }^{1,2}$ \\ ${ }^{1}$ Facultad de Psicología y Relaciones Humanas, Universidad Abierta Interamericana, Buenos Aires, Argentina \\ ${ }^{2}$ Centro de Investigaciones Sociales y Humanas para la Defensa, Universidad de la Defensa Nacional, Buenos Aires, Argentina
}

Email address:

mluciana.dpagmail.com (D. P. M. Luciana), lic_pablodepaula@yahoo.com.ar (D. P. Domingo)

${ }^{*}$ Corresponding author

\section{To cite this article:}

Della Pittima María Luciana, Depaula Pablo Domingo. Social Emotional Climate and Social Well-being in a Sample of Public Transport Users of the Southern Zone of Greater Buenos Aires. American Journal of Traffic and Transportation Engineering. Vol. 4, No. 6, 2019 , pp. 149-154. doi: 10.11648/j.ajtte.20190406.11

Received: February 26, 2019; Accepted: April 15, 2019; Published: December 19, 2019

\begin{abstract}
Social Emotional Climate was developed by De Rivera (1992), as the presence of collective emotions generated in a determined temporal and socio-economic context, broadening the approach that emotions are felt in an individual way only. The aim of this research was to investigate the levels of Emotional Social Climate and Social Well-being in public transport users, and if there are differences between the context of the different transports and the relation between the above mentioned variables. In order to verify this associations, a sample of 300 public transport users was selected, with 149 bus passengers and 151 train users who travel from the Southside of Great Buenos Aires, to Buenos Aires City. The average age of the sample was 35.57 (SD 10.64, Minimum: 18 Maximum: 68). The study was quantitative, correlational and differential with groups. The instruments used to assess these variables were the Scale of Social Emotional Climate (CE, De Rivera, 1992) and the Scale of Social Well-being (Keyes, 1998) in its Spanish version translated by Blanco and Díaz (2005). The results indicate a Negative Emotional Climate in general, but more representative rail users. In addition differences are observed in the dimensions of Social Well-being, presenting a better perception of it those who do not use the train as their transportation of preference. On the other hand, in the Emotional Climate and Social Well-being influence the different transport schedules used, people's activities during the trip and the reason why each medium is chosen.
\end{abstract}

Keywords: Emotional Social Climate, Social Well-being, Users, Southern Zone of Greater Buenos Aires

\section{Introduction}

In recent years, in a context of discomfort in relation to the public transport service of trains, different ways of expressing disagreement emerged between its users, exceeding the institutional procedures in the resolution of conflicts [20].

Rebón et al. (2010), in his research on forms of social disconformance in which users have a direct action in the system of public rail transport in the metropolitan area of Buenos Aires, raised the hypothesis that train users spontaneously express their dissatisfaction with the service.

On the one hand, we can to think that with these problems into play the concept of Emotional Social Climate, which reflects both the way people think and how most people feel in any situation, by judgments that are based on experiences and personal observations [2].

\subsection{Social Emotional Climate}

The concept of emotional climate refers to the collective emotions that predominate in a social context, determining that they are those generated through the interaction of the members of a group in particular environment, it is not simply the sum of individual emotions [5]. Emotions, norms and beliefs about interpersonal and group relationships are involved in given social settings [2, 4, 6, 5, 8, 25].

Conejero et al. (2004) argue the emotional climate reflects both what people think and what most people feel in certain 
situation, through judgments based on personal experiences and observations, as well what others say. Ruiz (2007) and Zubieta et al. (2008), emphasize that in this way, subjective as well as intersubjective realities are formed, and Fernández-Dols et al. (2007), add that by means of these emotions it is possible to show the predominant social environment.

The emotional climate encompasses, on the one hand, the feeling of security of people, the feeling comfort in sharing beliefs and also the experience of anger and hopelessness in front of the government or the feeling of hope in the future of their country and also implies trust and respect between individuals in society [6]. Continuing the idea of the authors, the emotional climate is a collective affection that is presented in the interaction of individuals, as collective responses to their economic, political and social conditions.

Barbalet (1998 cited for Zubieta, Valencia, \& Delfino, 2014), points out that a collective emotion can lead to a common action with group objectives even when each person in the group personally experiences different emotions.

Páez et al. (1997), added about the emotional climate, that it is like an emotional state to collective level, manifested by an affective mode, by the repetition of specific emotions and a look and social representation about the world, the future and some behaviors related to emotions that are marked through interactions between people.

\subsection{Social Well-being}

On the other hand, the perception of Social Well-being is made visible, defined by Keyes (1998), as the valuation we make of the circumstances and the functioning within society. It emphasizes the need to consider the individual and the social, the given world and the intersubjectively constructed world, since both aspects of existence are related to well-being and health. Developing five dimensions $[1,14,16]$ :

1) Social integration. It has to do with evaluating the quality of the relationships we maintain with society and the community. People with high social well-being feel part of society, cultivate a sense of belonging and generate social bonds with family, friends, neighbours and other social groups.

2) Social acceptance. Refers to the trust, acceptance and positive attitudes towards others, as an attribution of honesty, goodness, kindness, capacity and the recognition of the positive and negative aspects of our life.

3) Social contribution. It is the feeling of being useful, as a vital member of society and that you have something to offer to the world. It has to do with profit, efficiency and contribution to the common good.

4) Social actualization. The conception that society and the institutions that make it up are efficient units that move in a direction related to the achievement of goals and objectives from which we can benefit. There is some confidence in progress and social change. There is security in the future of society, in its capacity for growth and development and to produce well-being.
5) Social Coherence. It is the perception of the quality, organization and functioning of the social world, and includes involvement what happens in the world. The feeling that is able to understand what is happening in the context in which we live.

\subsection{The Influence of the Emotional Social Climate and Social Well-being in the Public Transport}

Gutiérrez (2009), argues about what travel implies in a society, considering it as a social practice that implies competition of social behaviors, in a specific social, spatial and temporal context.

Faced with this practice that a large number of people perform daily, Pírez (1999) emphasizes that there would be a separation at the social level of the responsibility of each person in the functioning of the city as a condition of group life. And it continues with the idea that this fact, would indicate a loss of the social capacity of decision on the services and of social power on a basic component of the conditions of life in the city. This context of uneasiness in the face of the deterioration of the transport service does not cease with the passing of the years, becoming evident in the fall of the quality of life of the users of the metropolitan passenger railway of Buenos Aires city [18]. It is possible to rely on the analysis of Pírez (1999), who affirms that the provision of rail services evaluated negatively by the user population, presenting the most negative rating among public passenger transport as a whole.

The question we propose based on this theme is whether there is a relationship between the emotional social climate and social welfare. On the other hand, are these variables associated with train users and those who do not choose the train?

\section{Methodology}

\subsection{Design}

This is a correlational and group difference descriptive research [12]. We want to know the relationship between the social well being and emotional social climate. The groups we want to compare are, on the one hand train users and on the other hand bus users.

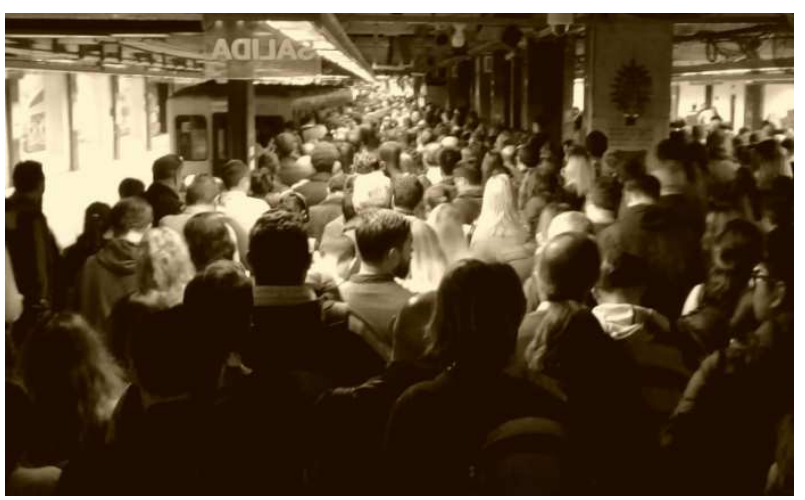

Figure 1. Transfer center at a peak hour. 


\subsection{Participants}

A non-probabilistic sample was selected for the convenience of 300 users: 151 railroad users of the General Roca Line, being the line with the largest number of passengers transported, those traveling daily from the Southern Zone of Greater Buenos Aires to Plaza Constitución (in the branches: Constitución - La Plata, Constitución Cañuelas, Constitución - Alejandro Korn, Temperley - Haedo and Temperley - Forests), and 149 bus users traveling daily from the Southern Zone of Greater Buenos Aires to Buenos Aires city contemplating the route of the same areas towards Buenos Aires city. The sampling selection and the mentioned characteristics were based on the indicators compiled by the Ministry of Transport through the CNRT (2015).

\subsection{Instruments}

\subsubsection{Social Emotional Climate Scale}

To measure Social Emotional Climate, we used the The Social Emotional Climate Scale (CE, de Rivera, 1992), which describes situations of social level and social relationships that generate negative and positive emotions in people in general. It is composed of 24 items such as: "Do people have confidence in the existence of good opportunities to improve their life and that of their family?" The response continuum is from 1 (no) to 7 (completely) and the items are group in two underlying dimensions: Positive Social Climate (12 items; Cronbach's alpha $=.75)$ : an average score above 37.5 indicates a high positive climate. Negative Emotional Social Climate: an average score higher than 30.6 indicates a high negative climate in the sample. To obtain the Negative Climate (12 items; Cronbach's alpha $=.66)$ score the items must be added: $2,4,6,8,10,12,14,16,18,20,22,24$ and for the Positive Climate 1, 3, 5, 7, 9, 11, 13, 15, 17, 19, 21 and 23 .

\subsubsection{Social Well-being Scale}

To measure Social Well-being, we used the Social Well-being Scale (Keyes, 1998) in its Spanish version translated by Blanco and Díaz (2005), which assesses people's perception of aspects of the social environment that benefit psychological well-being.

The reliability coefficient for this scale was very satisfactory (Cronbach's alpha $=.85$ ). In 33 items with continuous response from 1 (totally disagree) to 5 (totally agree), and through obtaining the average score, assess the perception that people have about five aspects of the social environment that facilitate their psychological well-being: Social Integration (7 items; Cronbach's alpha $=.71$ ), Social Acceptance (8 items; Cronbach's alpha $=.83$ ), Social Contribution (6 items; Cronbach's alpha $=.79$ ), Social actualization (6 items; Cronbach's alpha $=.66$ ) and Social Coherence (6 items; Cronbach's alpha $=.53$ ).

For the analysis of their scores on this scale, they must reverse the item scores: $5,6,7,8,9,10,11,13,14,15,17,18$, $20,22,23,24$ and 25. Then add the items according to the sub-dimensions and divide by the total number of items of that dimension. Social Integration: 1, 2, 3, 4, 5. On top of 4 high
Social Integration. Social Acceptance: 8, 9, 10, 11, 12, 13. Above 3.83, Social Acceptation. Social Contribution: 16, 17, 18, 19, 20. Above 3.80 high Social Contribution. Social actualization: 22, 23, 24, 25, 26. Over 3.80 high Social actualization. Social Coherence: 28, 29, 30, 31. Over 3.50 high Social Coherence.

\section{Results}

\subsection{Analysis of Means to the Emotional Social Climate}

The results obtained through the analysis of means corresponding to the variable Emotional Social Climate indicated that there is a high perception of the Negative Climate over the Positive Climate, since an average score higher than 30.6, indicates a high level of the first, giving as a result in the sample 51.61. A score higher than 37.5 indicates a high Positive Climate, in the sample the average is 41.19. This means that to a greater extent the subjects evaluated have a perception of negative emotions in relation to the state of mind that predominates in the social group over feelings of security, trust and respect (see Table 1).

In terms of Social Well-being, we observed higher than average levels in the sample, Contribution, Updating and Social Coherence, which have to do with a feeling of utility as a member of society and concern about what happens in the world.

Table 1. Average scores of Emotional Social Climate and Social Well-being.

\begin{tabular}{llll}
\hline & & Mean & SD \\
\hline \multirow{3}{*}{ Social } & Positive & 41,19 & 11,876 \\
Emotional & Negative & 51,61 & 11,605 \\
Climate & CE 2 & 5,12 & 1,608 \\
& CE 15 & 3,03 & 1,421 \\
& CE 24 & 5,68 & 1,409 \\
& Social Integration & 3,79 &, 634 \\
Social & Social Acceptance & 3,19 &, 850 \\
Well-being & Social Contribution & 3,95 &, 751 \\
& Social Actualization & 3,72 &, 798 \\
& Social Coherence & 3,74 &, 829 \\
\hline
\end{tabular}

\subsection{Analysis of Correlation Between Social Well-being and Social Emotional Climate}

Regarding the correlation of Social Well-being with Social Emotional Climate, all its dimensions: Integration $(\rho=.398, p$ $=.000)$, Acceptation $(\rho=.458, p=.000)$, Contribution $(\rho$ $=.391, p=.000)$, Actualization $(\rho=.532, p=.000)$ and Coherence $(\rho=.283, p=.000)$ are positively and significantly associated with the Positive Emotional Climate and negatively with the Negative Emotional Climate, Integration $(\rho=-.395, p$ $=.000)$, Acceptation $(\rho=-.523, p=.000)$, Contribution $(\rho=$ $-.373, p=.000)$, Actualization $(\rho=-.478, p=.000)$ and Coherence $(\rho=-.293, p=.000)$ because these dimensions have to do with the assessment we make of circumstances and social functioning, while the climate is related to collective emotions, which prevailing in a certain social context, the Positive Climate has to do with the perception of positive emotions and in counterpart, the Negative Climate with the predominance of negative collective emotions (see Table 2). 
Table 2. Correlation between Social Well-being and Emotional Social Climate.

\begin{tabular}{|c|c|c|c|c|}
\hline & & & $\begin{array}{l}\text { Social } \\
\text { Emotional Negative } \\
\text { Climate } \\
\end{array}$ & $\begin{array}{l}\text { Social } \\
\text { Emotional Positive } \\
\text { Climate }\end{array}$ \\
\hline \multirow{10}{*}{ Rho de Spearman } & \multirow{2}{*}{ Social Integration } & Correlation coefficient & $-.395^{* *}$ & $.398^{* *}$ \\
\hline & & Sig. (bilateral) & .000 & .000 \\
\hline & \multirow{2}{*}{ Social Acceptance } & Correlation coefficient & $-.523^{* *}$ & $.458^{* *}$ \\
\hline & & Sig. (bilateral) & .000 & .000 \\
\hline & \multirow{2}{*}{ Social Contribution } & Correlation coefficient & $-.373^{* *}$ & $.391^{* *}$ \\
\hline & & Sig. (bilateral) & .000 & .000 \\
\hline & \multirow{2}{*}{ Social Actualization } & Correlation coefficient & $-.478^{* *}$ & $.532^{* *}$ \\
\hline & & Sig. (bilateral) & .000 & .000 \\
\hline & \multirow{2}{*}{ Social Coherence } & Correlation coefficient & $-.293^{* *}$ & $.283^{* *}$ \\
\hline & & Sig. (bilateral) & .000 & .000 \\
\hline
\end{tabular}

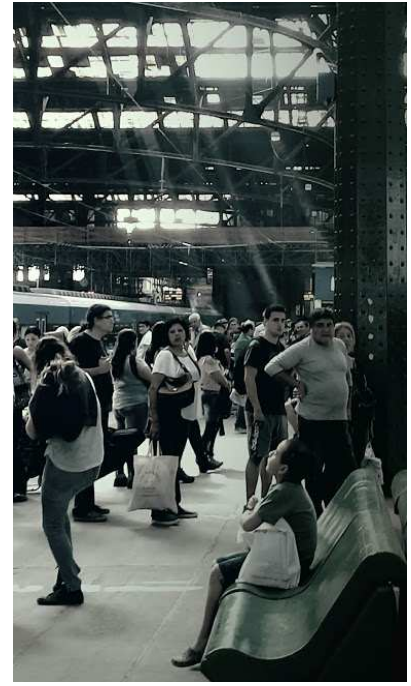

Figure 2. Plaza Constitución station

\subsection{Differences in the Ranges of the Emotional Social Climate and Social Well-being Among Users of Train and Other Means of Transport}

When performing the comparation between groups, significant differences were found between train users and those who do not travel in this means of transport. Mainly, with respect to the Emotional Social Climate, those who travel by train have a higher score of Negative Climate (Mann-Whittney $U=5868.500, p=.000$ ), that is, they have a predominant perception of negative collective emotions in comparison with those who do not travel by train, which obtained high levels of positive emotional social climate (Mann-Whittney $U=4866,500, p=.000$ ), which indicates that they have positive feelings at the social level; of respect, trust and security.

On the other hand, significant differences are observed in all the dimensions of Social Well-being; Integration (Mann-Whittney $U=6441.500, p=.000$ ), Acceptance (Mann-Whittney $U=5283.500, p=.000$ ), Contribution (Mann-Whittney $U=6152.500, p=.000$ ), Actualization (Mann-Whittney $U=6810.000, p=.000$ ) and Coherence (Mann-Whittney $U=7309.500, p=.000$ ), interpreting in this way that those who use the train as a means of preference to mobilize, have low score in these dimensions, that is, have a negative assessment of the functioning of society, while those who travel in other means of transport obtained high levels, considering that they have a positive perception with respect to the valuation and operation of society (see Table 3 ).

Table 3. Differences in the ranges of the Social Emotional Climate and Social Well-being between users of train and other means of transport.

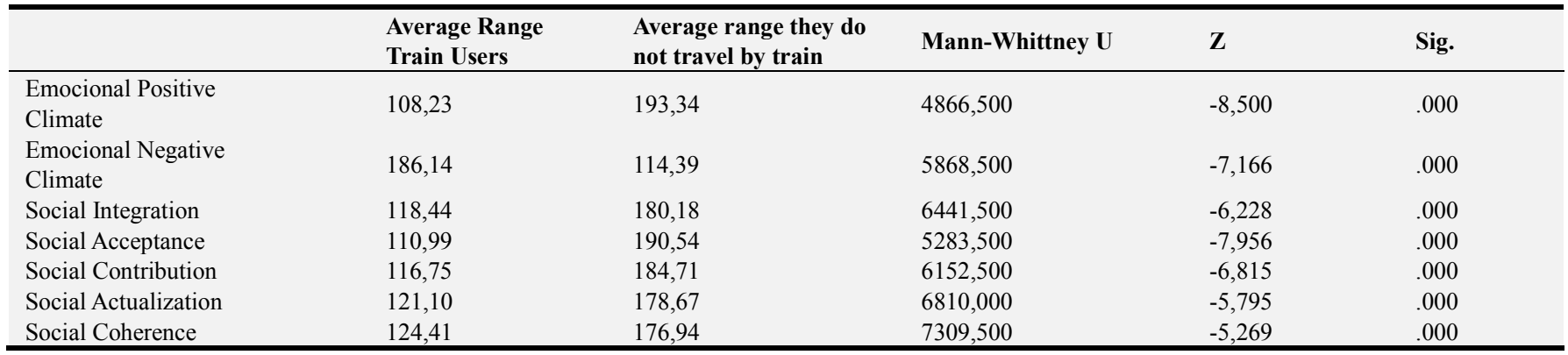

\section{Discussion}

The marked interest in rail transport, is due to the study, both the historical journey and the disconformance generated at the social level for various reasons. As a result of accidents and deterioration in the services, a climate is generate that users express their disagreement [22].

The obtained results show a significant difference of the Emotional Climate, between the users of the railway and the subjects that choose other transports. The first ones present high levels of Negative Emotional Climate.

The train, is used by a part of society to move daily and the 
use of it depends arrival on time for the realization of a daily activity, such as employment, academic training or even a medical shift, if it is taken into account the malfunctioning of this transport and the quality of travel and the results obtained, is possible inferring that this daily activity, the going from one place to another, directly influences the perception of Social Well-being, both in its dimensions that are related with confidence and positive attitudes with others as well as with those that contemplate the active part of the subject in society such as Contribution and Social Coherence. In relation to the aforementioned, Pírez (1999) say, who maintains that there is a social dislocation and an inability to make a social decision in the face of the deterioration of the train transport service. In addition, in the event of collapse due to the poor functioning of the railway, there is a disagreement among users, say Rebón et al. (2010) and this is reflected in the low scores of Social Well-being of users, contrasted with those who choose other means, since as mentioned by Fuentes (2012), the unpredictability of the train's working, makes people look for alternatives displacement, among these to bus transport.

Necessarily, we must continue with the concept of Emotional Social Climate, to better understand the results obtained in terms of Social Well-being, since in the dimensions of it social aspects are presented that have to do with positive relationships with others that are generated in a determined environment and the Emotional Social Climate involves the feelings and emotions that are generated in a specific context at a social level, De Rivera (1992) considers that they are collective emotions that transcend to the individual.

Regarding the relationship of the aforementioned variables, previous studies indicate a negative association between the Negative Emotional Climate and the Acceptance, Updating and Social Coherence perceived by the subjects [26]. The results obtained in the research are related to all the dimensions of Social Well-being, since the higher the score of the same, the Positive Climate was higher, and as the level fell in the Well-being dimensions, the greater was the predominance of negative emotions perceived in the subjects, that is, of the Negative Emotional Climate. These results can be understood in a similar way as with the previous variable, since a bad performance of rail transport directly affects the perceived social emotions and positive relationships with others, as well as those who choose other means such as collective transport for reasons of comfort, manifest a perception of positive emotions over negative ones.

Faced with the results obtained and developed so far, we can refer to studies conducted at different times by Simmel (1903, Miller, 1964 and Milgram, 1970 cited in Dorantes Rodríguez \& Matus García, 2002), about the psychological imbalance that results from the life in cities, generating a filter in the information that people receive and avoiding social contacts, could be understood for the same reasons to those users who prefer to travel in more comfortable conditions, without giving greater importance to speed. Pírez (1999) develops about the disengagement of social responsibility that affects transport users and life in the masses, adding that there is a decrease in respect in interpersonal relationships, which is reflected in the information developed above.

Other data obtained that we would like to highlight is the association of these variables with those socio-demographic data that were considered important for the present investigation. It is observed that there is a relationship between travel time, Social Well-being and the Emotional Climate. There is a negative emotional climate and low perception of the dimensions of Social Well-being in those users traveling to the Buenos Aires city, before 09:00 AM, and those traveling after 09:00 am have higher Positive Climate values and in the Integration, Acceptance and Social Actualization dimensions. The same happens in the case of the hours before 05:00 pm, back to Southern Zone of Greater Buenos Aires [3]. To understand this information, it is necessary to consider data from the Transport Institute, from the National Academy of Engineering (2011), which maintain that the lines that present a problem of saturation and comfort in the peak-hour, then we understand that what characterizes the "peak hour", considering the time of day in which a greater number of people move, directly influences the emotions perceived by users and the perception of social functioning. Those who travel before 09:00 am have greater limitations when to think about correct social functioning, evidencing in the low scores in the Social Actualization dimension and there is a predominance in the perception of negative emotions in the relationship with others. Negative Emotional Social Climate, the lack of comfort and saturation that at times could be called "overcrowding", cannot generate feelings and positive emotions.

As it is being developed and already mentioned, there is a relationship between the reason for choosing the mode of displacement, Social Well-being and Social Emotional Climate. Those who choose it for convenience have higher scores in the dimensions of Social Well-being and in the perception of positive collective emotions, while those who choose it for speed, obtain high levels of Negative Emotional Social Climate and low scores in the assessment of performance of society, that is, of Social Well-being.

By way of conclusion, we could consider the importance of the present investigation, since the data obtained support some of the hypotheses, such as that rail transport users have a Negative Emotional Social Climate in comparison to those who choose automotive transport, and reinforce research data from various disciplines that study about the influence of transportation on society. Displacement is a social fact and directly influences the daily activities of people, which is why it is necessary to denature the bad conditions of travel. It could also be taken into account for future research, the fact that people who do something while traveling, such as reading a book or using cell phones, have a prevalence in the perception of positive emotions, compared to those who do not perform any specific activity, which is relevant to consider that the distraction or entertainment in the transport trip positively influences the Positive Emotional Social Climate.

Knowing the variations of the Social Emotional Climate and Social Well-being in public transport users opens a wide 
range of interests towards various disciplines, since it affects the interest of those who study about social functioning, the agglomeration of large cities and the conditions of transport.

This research provides empirical data that would allow us to delve into future research, taking into account the psychological perspective, towards the behaviors of people in society, in order to build strategies for change or improvement in emotions at a collective level and in quality of interpersonal relationships.

\section{References}

[1] Blanco, A. \& Díaz, D. (2005). Social well being are: concept and measurement. Psicothema, 17 (4), 582-589.

[2] Conejero, S., De Rivera, J., Páez, D. \& Jiménez, A. (2004). Alteración afectiva personal, atmósfera emocional y clima emocional tras los atentados del 11 de marzo. Ansiedad y Estrés, 10 (2-3), 299-312.

[3] Della Pittima, M. L., \& Depaula, P. D. (2018). El Bienestar Social asociado a los Valores Humanos en usuarios de transporte público de la Zona Sur del Gran Buenos Aires. Revista Transporte y Territorio, 18, 285-309.

[4] De Rivera, J. (1992). Emotional climate: Social structure and emotional dynamics. International Review of Studies on Emotion, 2, 197-218.

[5] De Rivera, J. \& Páez, D. (2007). Emotional climate, human security and cultures of peace. Journal of Social Issues, 63 (2), 233-253.

[6] De Rivera, J., Kurrien, R. \& Olsen, N. (2007). The emotional climate of nations and their culture of peace. Journal of Social Issues, 62 (2), 255-272.

[7] Dorantes Rodríguez, C. H. \& Matus García G. L. (2002). El estrés y la ciudad. Revista del Centro de Investigación. 18 (5), 71-77.

[8] Espinosa, A., Herschkowicz, S. \& Genna, K. (2011). Correlatos psicológicos de las intenciones y comportamientos migratorios de jóvenes peruanos de clase media y alta. Perspectivas Individuo y Sociedad, 10 (1), 99-124.

[9] Fernández-Dols, J., Carrera, P., Hurtado de Mendoza, A. \& Oceja, L. (2007). Emotional Climate as Emotion Accessibility: How Countries Prime Emotions. Journal of Social Issues, 63 (2), 233-253.

[10] Fuentes, A. (2012). Cuestiones urbanas y regionales en Argentina. Procesos y prácticas en la ciudad contemporánea. Territorios en construcción. Ponencia presentada en VII Jornada de Sociología de la UNLP. Universidad Nacional de La Plata, La Plata, Argentina.

[11] Gutiérrez, A. (2009). Movilidad o inmovilidad: ¿Qué es la movilidad? Aprendiendo a delimitar los deseos. XV Congreso Latinoamericana de Transporte Público y Urbano, XV CLATPU, Buenos Aires.

[12] Hernández Sampieri, R., Fernández Collado, C., \& Baptista Lucio, M. (2010). Metodología de la Investigación. México: McGraw-Hill.

[13] Instituto del transporte Academia Nacional de Ingeniería.
(2011). Accesos a la región metropolitana de Buenos Aires. El transporte ferroviario y los subterráneos. (2). Recuperado de $\mathrm{http}: / /$ www.acadning.org.ar/Institutos/ANI\%20-instituto\%20d el\%20Transporte $\% 20$ Estudio\%20Estrategico\%20Preliminar $\%$ 20Accesos\%20RM\%20\%20\%20v003.pdf

[14] Keyes, C. (1998). Social well-being. Social Psychology Quarterly, 61, 121-140.

[15] Keyes, C., Ryff, C., \& Shmotkin, D. (2002). Optimizing well-being: the empirical encounter of two traditions. Journal of Personality and Social Psychology, 82, 1007-1022.

[16] Keyes, C. \& Shapiro, A. (2004). Social Well-Being in the United States: A Descriptive Epidemiology. En O. G. Brim, C. D. Ryff \& R. C. Kessler (Eds.), How Healthy Are We?: A National Study of Well-Being at Midlife (pp. 350-372). University of Chicago Press.

[17] Ministerio de Transporte, Comisión Nacional de Regulación del Transporte (2015) Informe estadístico 2015 de la red ferroviaria argentina. Recuperado de http://www.cnrt.gob.ar/content/estadisticas/ferroviario

[18] Müller, A. (2015). Ante un nuevo ciclo: delineando un futuro para el ferrocarril interurbano en la Argentina. (Documento $\mathrm{n}^{\circ}$ 42). Recuperado de http://blogdelcespa.blogspot.com.ar/p/documentos-de-trabajo. html

[19] Páez, D., Ruiz, J. I., Gailly, O., Kornblit, A. L., Wiesenfeld, E. \& Vidal, C. M. (1997). Clima emocional: Su concepto y medición mediante una investigación transcultural. Revista de Psicología Social, 12 (1), 79-98.

[20] Pérez, V. (2010). La gestión del sistema ferroviario urbano de pasajeros. Un terreno fértil para el desborde hostil de los disconformes (1994-2008). Revista Transporte y Territorio, 3, 103-123.

[21] Pírez, P. (1999). Gestión de servicios y calidad urbana en la ciudad de Buenos Aires. Eure (Santiago), 76 (25).

[22] Rebón, J., Quintana, G., Pérez, V., Álvarez, J., Gamallo, L., Hernández, M., \& Tafuro, S. (2010). Trenes en llamas. La disconformidad social entre los usuarios del sistema público de transporte ferroviario del área metropolitana de Buenos Aires. Revista Theomai, 21, $77-95$.

[23] Ruiz, J. I. (2007). Emotional Climate in Organization: application to Latin American prisons. Journal of Social Issues, 63, 289-306.

[24] Zubieta, M., Delfino, G. \& Fernández, O. (2007). Confianza institucional y el rol mediador de creencias y valores. Revista de Psicología, 3 (6) 101-120.

[25] Zubieta, E. M., Delfino, G. I., \& Fernández, O. D. (2008). Clima social emocional, confianza en las instituciones y percepción de problemas sociales. Un estudio con estudiantes universitarios urbanos argentinos. Psykhe, 17 (1), 5-16.

[26] Zubieta, E., Fernández, O. \& Sosa, F. (2012). Bienestar, valores y variables asociadas. Boletín de Psicología, 106, 7-27.

[27] Zubieta, E., Valencia, J., \& Delfino, G., (2014). Culturas de paz y el clima emocional de las sociedades. Psicología Social y Política. Procesos teóricos y estudios aplicados. Buenos Aires: Eudeba. 